\title{
Genetic equity
}

\section{John Harris and John Sulston}

Abstract | This paper proposes, elaborates and defends a principle of genetic equity. In doing so it articulates, explains and justifies what might be meant by the concept of 'human dignity' in a way that is clear, defensible and consistent with, but by no means the same as, the plethora of appeals to human dignity found in contemporary bioethics, and more particularly in international instruments on bioethics. We propose the following principle of genetic equity: humans are born equal; they are entitled to freedom from discrimination and equality of opportunity to flourish; genetic information may not be used to limit that equality.

The prestige of genetics and the fears provoked by genetic science are both possibly at their zenith. The sequencing of the human genome, the promises of PHARMACOGENETICS and GENE THERAPY and the success of genetic fingerprinting in the identification of criminals have placed genetic techniques at the cutting edge of science and popular interest in science. Equally, fears about REPRODUCTIVE CLONING, 'designer babies', genetic enhancements of humans and other species, and fears that the abuse of genetic information will lead to unfair discrimination or forms of eugenic genetic cleansing, have occasioned an almost unprecedented mistrust of science. Not all fears of science are either rational or justified, of course, and there is little or nothing that can be done about some of these irrational fears other than waiting for the passage of time. Jonathan Swift is often credited with having observed that "It is impossible to reason a man out of something that he has not been reasoned into." However, fears concerning the abuse of genetics resulting in discrimination or in violations of human rights are both rational and reasonable and it is, we believe, particularly incumbent on scientists to take a principled stand against such abuses. We therefore propose a firm commitment to genetic equity, and this paper elaborates the basis and the justification for such a principle. Some commentators consider that such an emphasis on genetics - so called GENETIC EXCEPTIONALISM - is misguided, but although we do not believe that genetics raises unprecedented or qualitatively different issues, we do think that there are good reasons to focus more general principles specifically on genetics.

In listening to, and participating in, many discussions about the social consequences of the rapidly increasing power of human genetic knowledge, we have found ourselves despairing at a tendency towards what might be termed genetic unexceptionalism: a feeling that 'the devil is in the detail' and that the best that can be done is to start from scratch in each case. It is true that grand generalizations are not a sufficient guide to good social conduct and law-making. However, detailed investigation is an insufficient guide to dealing with the future; we not only need to lift our gaze from the ground to the horizon, we urgently need a compass to indicate which points on the horizon are in the right direction. In developing a principle of genetic equity, we are proposing a compass point to guide the direction of genetics. We also propose a new and, we believe, more fundamental and coherent concept of human dignity. 


\section{The basis of genetic equity}

There is a strong presumption in our society, and indeed in most others, that individuals' MORAL CLAIMS derive from their dignity and standing as humans. This dignity and standing might be explained or justified in a number of ways, although usually they are simply taken as given, as a sort of axiom in the system or as a familiar and accepted principle of shared morality. When we appeal, for example, to 'human rights' (see BOX 1), we are appealing to and drawing on what we believe to be a shared morality, a set of agreed longstanding principles that are so generally accepted that we can rely on others to both understand and to respond to our appeal.

Here, we propose the recognition of what we hope will prove to be a new human right. Not new in the sense of being unprecedented and original; in fact, we believe that what we propose is implicit in existing morality and systems of rights. Instead, it is new in the sense that it becomes explicitly acknowledged and recognized as a right. We are interested in the question of the extent to which human rights or moral claims extend to protection against discrimination on the basis of genotype or features that it determines. What we say here applies to all those who come within the protection of the principle of respect for persons or for human rights.

When appeals are made to human rights, or reference is made to the moral claims that humans can make in virtue of their humanity, it is generally accepted that the strength of such claims is not diminished by a number of arbitrary or CONTINGENT FEATURES that have classically been the object of irrational and vicious prejudice. The 'usual suspects' here are race, religion, colour, nationality, ethnicity, gender and, more recently, sexual orientation. Our question is whether the genome or genetically determined features should be added to this list.

Appeals to human rights or to respect for individuals are necessarily made at a high level of generality. It is this generality that is found in almost all declarations of, or conventions on, human rights. However, the principle that an individual's entitlement to the concern, respect and protection of the community does not vary with such arbitrary features as race, gender or genome accords well with the widely held belief in equality. More particularly, genetic equity means that our claims on one another and our mutual obligations derive from our status as beings of a particular sort and not from contingent features of our lives, such as gender, race or genetic constitution.

It is important to stress that a commitment to equality as a moral and political ideal

\section{Box 1 | The concept and scope of human rights}

In this paper, we take as established, or at least unproblematic, that there are rights, that they ground moral claims and that human persons are able to make the strongest of such moral claims and appeal to the protection of 'human rights'. Although, of course, for philosophers with a broadly CONSEQUENTIALIST perspective (which includes the authors of this article), rights including human rights - are never axiomatic, but are justified only as the conclusions of moral arguments and never as one of the premises. Arguments could and have been given in support of the particular rights and interests to which we refer, but they will not be given prominence here.

Although human rights in one form or another command almost universal respect, there will necessarily be arguments about scope. Scope concerns the range of individuals that are able to make moral claims and the precise nature of those claims. For example, there are arguments over whether or not embryos and fetuses are included within the scope of 'human persons' or whether the right to life, or the obligation to respect the sanctity of life, permits war or capital punishment. These are questions, inter alia, of scope. Those who disagree about such things do not usually disagree about the importance of the sanctity of human life or as to whether murder is the most serious of moral offences. By contrast, they disagree about whether or not a particular case is in fact a case of murder or whether the individual killed was a person in the relevant sense.

Important as questions of scope are, we are not centrally concerned with such questions here, partly because the disputes about scope are about as intractable as disputes can be. For the purposes of this paper, we follow recent legal decisions, which confirm that the unborn are beyond the scope of principles such as those with which we are concerned ${ }^{21}$.

does not involve any claim that people are or should be 'the same', except with respect to their rights or interests, or with respect to their moral claims. For example, as Simona Giordano has recently pointed out ${ }^{1}$, “....nearly 30 years before the French Revolution offered one of the most important declarations of 'equality' of all times (1789), Jean Jacques Rousseau pointed out that the notion of equality may have different meanings, and that it is important to clarify what we mean by 'equality'. For example, saying that 'men are equal' does not of course mean that they are 'morally' equal (in rights and by convention)" 1 . Indeed, in the eighteenth century, Jean Jacques Rousseau noted that, “....instead of destroying natural equality, the fundamental covenant substitutes a moral and legitimate equality for the physical inequality that nature may have set up among men, and those who may be unequal in strength or intelligence become equal by convention and legal right"'.

In contemporary philosophy, many have built on Rousseau's insight, which itself can be traced back to Plato ${ }^{3}$. Among them, Ronald Dworkin has distinguished between treating people equally and treating them 'as equals'4 Dworkin is referring to a citizen's rights to equality, and he identifies two different such rights that citizens might be said to have: "The first is the right to equal treatment, which is the right to an equal distribution of some opportunity or resource or burden. Every citizen, for example, has a right to an equal vote in a democracy... The second is the right to treatment as an equal, which is the right, not to receive the same distribution of some burden or benefit, but to be treated with the same respect and concern as anyone else. If I have two children and one is dying from a disease that is making the other uncomfortable, I do not show equal concern as I flip a coin to decide which should have the remaining dose of a drug."

By saying that the right to equal treatment derives from the fundamental right to treatment as an equal, Dworkin identifies that equal treatment is indicated only where it is a plausible interpretation of the demand for treatment as an equal. Therefore, giving each person an equal vote in a democracy is what is required for each to be accorded the same concern and respect as any other; as in the words of Jeremy Bentham ${ }^{5}$, “...everybody to count for one, nobody for more than one”. Similarly, with Dworkin's two imaginary children, he shows that he values each equally by treating them differently and giving the drug to the one who needs it to survive rather than to the other, who will only be made more comfortable. On the other hand, if both needed the remaining dose of the drug to stay alive and there was only enough to save the life of one of them, it is demonstrated that each child is valued equally by deciding between them in a way that shows no preference for one over the other - by drawing lots, for example.

A belief in equality is underpinned, and in a sense explained, by the idea that those who are considered to have a right to treatment as equals, or whom we have a duty to treat as equals, are of equal value - are equally morally significant. This, after all, is what makes Dworkin's example so compelling. We are to presume that he values both his children equally and so wants to know how to act in a way that respects this equal valuation. 
The reasons why each of his children must be thought of as equally valuable both explain and justify treating them as equals. And of course, the same is true for all of us. The requirement that each of us be treated as the equal of anyone else rules out genetic discrimination or any other form of unfair discrimination.

All democratic societies must treat their citizens as equals, according to each the same concern, respect and protection, in the protection of their laws and customs and also in the allocation of public resources or even in the deployment of private resources to secure public goods. For example, if a private commercial organization, such as a pharmaceutical company, develops a vital treatment or vaccine, it is the obligation of society to ensure that access to this drug or treatment is available in a way that does not unfairly discriminate for or against some sections of that society - those of a particular race or religion or members of the governing political party. The scope of this principle might of course be contested - for example, as to whether or not it covers discrimination on the basis of ability to pay or the degree of benefit that could be derived from the treatment ${ }^{6-10}$.

Both in view of the above arguments and because we believe equal respect for all persons is an integral and ineradicable part of democratic theory, and therefore an essential feature of all liberal democracies, we believe that a principle of genetic equity should be explicitly added to our understanding of the requirements of both equity in general and of the requirements of democratic polity. Societies have a fundamental obligation to ensure the protection of the life, liberty and health of each citizen impartially, and to provide access to "...humans are born equal; they are entitled to freedom from discrimination and to equality of opportunity to flourish; genetic information may not be used to limit that equality."

beneficial health care and to the fruits of research on the basis of individual need, so that each has an equal chance of flourishing to the extent that their individual genome and personal health status allows. This equal chance of flourishing should be protected by the state, regardless of such arbitrary features as race, gender, genome, degree of disability, wealth and power, religious belief or skin colour.

Genes (or genetic constitution) are clearly some of the most important examples of the personal characteristics that make a difference to how people are able to function and often to how they are perceived, but they are also features that, as yet, have not been adequately incorporated into our understanding of the requirements of both equity and democracy.

\section{A principle of genetic equity}

We propose the following principle of genetic equity: humans are born equal; they are entitled to freedom from discrimination and to equality of opportunity to flourish; genetic information may not be used to limit that equality.

It follows that neither genetic constitution nor genetic information should be the basis of

\section{Box 2 | Unfair discrimination}

The question of when and why discrimination is unfair cannot be precisely or definitively resolved. There are many ways in which something might be unfair and new insights are always arising (see the example in the main text of Dworkin's distinction between equal treatment and treatment as an equal). Far from it being a strength to try to define the difference between fair and unfair discrimination, it would be both impossible in anything short of a paper on its own and, more importantly, it would be undesirable. Practices might be unfair in many ways and there will always be debates over whether or not something is unfair. Take, for example, the practice of AFFIRMATIVE ACTION in education and employment ${ }^{22}$. It is still debated as to whether being a member of a disadvantaged group should count affirmatively when seeking educational opportunity or employment along with the other things that traditionally count as qualifications, such as educational attainment. The fairness of such practices cannot be settled by a more precise definition of 'fairness', but requires evidence, argument and knowledge of the impact of past practices. Moreover, precision is sometimes unhelpful. It is, for example, a strength - not a weakness - of the First Amendment to the American Constitution that it does not define 'speech' when it protects free speech. The US Supreme Court has repeatedly extended our normal concept of speech to include new and important modes of expression - flag burning, for example. The aim of the principle of genetic equity is to remind us that discrimination on the basis of genetic factors is wrong unless it can be demonstrated that it is not unfair. The burden of proof is on those who would discriminate to demonstrate the fairness or justice of so doing.

discrimination or stigmatization of an individual, family or group. No individual's genes, or genetic information about them, can or should detract from their equal standing and dignity in the community and their equal entitlement to the concern, respect and protection of others or of society.

We recommend that this principle be incorporated into the legislation and practice of all societies and that nations should work towards its international acceptance. Respect for genetic equity will express itself as the opposition to unfair discrimination between individuals ( see BOX 2), in the defence of equality of access to primary social goods, including employment, financial security and health care, regardless of genetic considerations, and in access to genetic information about ourselves.

We prefer the term 'genetic equity' to 'genetic equality' to emphasize that both our concern and, we believe, the concern of society, should be to secure fairness and justice rather than simply to eradicate difference. It is clear that genetic equity, as understood here, is derived from political and moral ideas of equality.

An important part of any approach to equality is the question of whether or not people's legitimate moral claims are relative to a number of things that might be true of them, such as their genetic constitution, the quality of their lives (present or anticipated) and other capacities that they might have or lack. By legitimate moral entitlements, we mean a person's sustainable claims or entitlements to the concern, respect and protection of the community and of other individuals as expressed in two main ways.

First, they are expressed in the form of legal protections, whether these take the form of eXpresS STATUTORY ENTITLEMENTS Or COMMON-LAW RIGHTS, or more vague protections, perhaps in the form of rights protected by international conventions to which states are signatories, or less formal ethical protocols such as the WORLD MEDICAL ASSOCIATION DECLARATION OF HELSINKI ${ }^{11}$ (see Online links box for further information). Second, they are also expressed in the form of entitlements to access to, or provision of, public resources or services.

These moral claims are often, as we have noted, expressed in terms of 'rights' or 'human rights', but such rights have always to be established by the arguments that sustain them. They are never legitimately simply 'given' or 'taken for granted'.

\section{Gene-relative moral claims}

This principle of genetic equity is, as we have suggested, the application of a more general principle: that each person is entitled to the 
same concern, respect and protection of society as is accorded to any other person. This principle of equality has the advantage of wide appeal and acceptance, and versions of it are enshrined in many national constitutions throughout the world - for example, those of the United States and France - and in various declarations of human rights ${ }^{12,13}$. The principle of genetic equity reminds us that the principle of equality applies as much to discrimination on the basis of genome as it does to discrimination on the basis of gender, race and other arbitrary features?

The principle of genetic equity is derived from strong moral arguments; it summarizes those arguments and presents the conclusions in a form that also acquires an independent resonance and appeal. This independent resonance and appeal is derived in part from the principle's reflection of a pre-existing and accepted morality, from the ways in which it extends or makes clearer the application and relevance of that morality, and from the way the power of the language in which it is expressed adds to its appeal. The strength of a clearly articulated principle that is resonant enough to be inspiring and at the same time firmly grounded in established moral theory, custom and practice, lies in the way it can inform and guide a community's approach to a broad range of legislative, policy and funding initiatives. Can we be confident, however, that this principle of genetic equity is reasonably well grounded in moral theory, custom and practice?

An appeal to common-sense morality? In addition to the strong moral and political arguments that support the equality principle and its daughter, the principle of genetic equity, both principles appeal to common sense. If people matter morally, then discrimination between them can only be justified in three main ways. First, if it can be shown that they are not after all 'persons' in the relevant sense, if they are beyond the scope of the principle. Second, if the proposed discrimination can be shown to be consistent with equality or equity, if it can be shown to be consistent with treating each person with the same concern and respect and according to them the same protection of the community as, any other. Third, discrimination might be justified on the grounds that it is what the individuals themselves desire or at least have consented to, or, if they are incapable of giving consent, that it is in their best interest.

As we have suggested, this is basic common sense. If you hear that one hundred innocent people have been murdered, the offence would hardly be mitigated if it

\section{Glossary}

AFFIRMATIVE ACTION

The practice of counting features such as gender or skin colour affirmatively as a qualification for educational or employment opportunities to mitigate or help to eradicate the effects of discrimination.

\section{COMMON-LAW RIGHTS}

The rights that arise in common-law jurisdictions such as England and the United States, which are usually rights that are traditionally recognized by the courts (case law), as opposed, for example, to rights established by a parliament (statute law).

\section{CONSEQUENTIALIST}

A person who adheres broadly to the philosophical idea of consequentialism, which holds that actions are to be ethically evaluated in terms of their consequences, rather than in terms of the agent's intentions or some absolute standard.

\section{CONTINGENT FEATURES}

Features that are not necessary or logically entailed.

\section{GENETIC EXCEPTIONALISM}

The singling out of genetic criteria for special attention, often with the implication that it is inappropriate to do so.

GENE THERAPY

The introduction of an active gene into a patient to supply a missing function or to offset susceptibility to a disease.

emerged that the victims were all elderly people, children, severely ill hospital patients, or had a particular gene or set of genes. Suppose the same one hundred people stood in need of rescue, what would lessen our sense of the moral importance of saving their lives? Only factors that would have this effect can identify features that would plausibly diminish the moral status of individuals.

We have advanced the principle of genetic equity as an appropriate moral principle to guide initial steps in the regulation of genetics. We hope that it expresses in memorable form an idea that is already part of our common-sense morality and, moreover, that has a strong intuitive appeal.

\section{Equal protection}

Arguably, protecting citizens against threats to their lives, liberties and fundamental interests is a priority for any state. In 1651, Thomas Hobbes wrote: "The obligation of subjects to the sovereign, is understood to last as long, and no longer, than the power lasteth, by which he is able to protect them." 14

In this view, any citizen's obligation to the state and its laws is conditional upon the state protecting that citizen against threats to his or her life and liberty. Ronald Dworkin echoes Hobbes in his recent book Sovereign Virtue: "No government is legitimate that does not
KANTIAN ETHICS

In broad terms, the name given to a trend in ethics that follows the ethical approach of Immanuel Kant. In this context, it refers to the idea that people should be treated always as ends in themselves and never only as a means to the ends of others.

MORAL CLAIMS

Claims that people make on each other or society, the justification of which is ethical rather than legal or customary.

PHARMACOGENETICS

Pharmaceutical treatment that is tailored to the individual, with regard to genetic criteria - for example, by choice of drug or dosage.

REPRODUCTIVE CLONING

Cloning, either by nuclear substitution or by embryo splitting, resulting in a live birth. It occurs naturally in the case of identical twins.

STATUTORY ENTITLEMENTS

The rights established by statute or other acts of the legislature.

WORLD MEDICAL ASSOCIATION DECLARATION OF HELSINKI

A declaration of principles and standards for humansubject research that is widely accepted in the research community.

show equal concern for the fate of all those citizens over whom it claims dominion and from whom it claims allegiance. Equal concern is the sovereign virtue of political community - without it government is only tyranny." ${ }^{15}$

Another feature of the state's obligation to defend its citizens that is often overlooked is its egalitarian and impartial nature. Just as each citizen has an obligation to obey the law regardless of such features as race, religion, gender, genetic constitution or quality of life, so the state must discharge its obligation of protection with the same impartiality. If we expect people to obey the law, we must not deny them the equal protection that is an essential part of the social contract. The basis of both our obligation to them and their claim on us is the equal standing of all of us as individuals, entitled to equality of concern, respect and protection in virtue of our status as full moral individuals.

\section{Human dignity}

A further advantage of the principle of genetic equity as we have formulated it is that it clarifies an idea that comes, we believe, closer than any to putting flesh on the bones of the much used and abused concept of 'human dignity'. In many cases, human dignity is appealed to without any further explanation or clarification (for example, see 
REF. 16), but those who trace it to KANTIAN ETHICS make the best job of giving it a coherent and testable formulation.

An example of an appeal to a Kantian principle of human dignity was given by Axel $\mathrm{Kahn}^{17}$ : "This principle demands that an individual - and I would extend this to read human life - should never be thought of as a means (sic), but always also as an end."

Kahn meant, of course, to say "merely as a means", but his use of Kant, as with many that appeal to human dignity, makes it very difficult to separate legitimate from illegitimate uses of others for one's own purposes ${ }^{18}$. "Respect for human dignity requires that an individual is never used...exclusively as a means" ${ }^{19,20}$, but the principle is not violated so long as, in addition to using someone as a means to our own ends, we treat them as ends in themselves. Many people marry to have children, for example, but so long as their marriage partner is also treated as an end in him- or herself the principle is not violated. As human motives are almost always mixed in this way, it is difficult to find violations of human dignity in Kant's and Kahn's terms and so such appeals are almost always unhelpful in assessing the ethics of any proposed action.

\section{What is 'human dignity'?}

Grounding genetic equity in the idea of the equal standing of each person, the idea that each is entitled to the same concern, respect and protection as is accorded to any - in Bentham's formulation of the idea that each is to count for one and none for more than one - we have a clearer idea of what constitutes human dignity and what derogates from it. Furthermore, this picture is instructive and can guide action in the sense that all moral principles must do. Human dignity is expressed in this view in terms of equal standing in the community and in equal respect for rights and interests. Bentham's phrase is, we believe, revealingly apposite, containing as it does two ideas 5 . First is the idea of counting equally - if one person counts for one, then two count for two, and so on. This idea shows us why we always have a moral reason to save more lives rather than fewer; because each life matters equally. Bentham's second idea contains the thought that people not only matter numerically, but that they also count in a more absolute and existential sense they count for something! In short, they matter; they count because they have equal dignity and standing.

\section{Conclusion}

Genetic equity is already well established for certain traits, notably gender and colour. With the rapidly increasing ability of science to analyse genetic information, the time has come to extend the concept of genetic equity to guarantee non-discrimination to everyone. Such a general principle can then provide the basis for informed, detailed discussions about matters such as the role of genetic features in, for example, insurance and employment, and thereby alleviate practical concerns about misuse of the information. Privacy of genetic information is generally accepted as important for human rights and what is often called human dignity. It is a good first line of protection, but on its own it is not enough. It is subject to breach by human error, theft and misuse of data by those in authority. Attempts to achieve absolute privacy are leading to tortuous complications in so-called informed consent. We need a further and more effective line of protection for the rights of the individual; one that avoids some of the problems of scope discussed earlier by clearly applying to those who are already recognized as members of the community, with individual rights and interests. This is what we have attempted to describe here. We have also proposed a new concept of human dignity, which we believe will ground this muchabused idea in reality and in a usable principle of morality.

\section{John Harris is at the Institute of Medicine, Law and Bioethics, School of Law, University of Manchester, Oxford Road, Manchester M13 9PL, UK.}

John Sulston is at the Wellcome Trust Sanger Institute, Wellcome Trust Genome Campus, Hinxton, Cambridgeshire CB10 1SA, UK. doi: $10.1038 / \operatorname{nrg} 1454$

1. Giordano, S. Do elderly people have human rights? Respect for equality and the treatment of the older person: declarations of human rights and age-based rationing. Camb. Q. Healthc. Ethics (in the press).

2. Rousseau, J. J. Du Contract Social, ou Principes du Droit Politique (Chez Rey MM, Amsterdam, 1972).

3. Plato The Republic Book V 451-457 (Stephanus edn, 1578).

4. Dworkin, R. Taking Rights Seriously 227 (Duckworth London, 1977).

5. Mill, J. S. in Utilitarianism (ed. Mary Warnock) 319 (Collins/Fontana, London, 1962).

6. Harris, J. Does justice require that we be ageist? Bioethics 8, 74-84 (1994).

7. Harris, J. Could we hold people responsible for their own adverse health? J. Contemp. Health Law Policy 1 100-106 (1996)

8. Harris, J. What is the good of health care? Bioethics $\mathbf{1 0}$, 269-292 (1996)

9. Daniels, N. Just Health Care (Cambridge Univ. Press, 1985).

10. McKie, J. et al. The Allocation of Health Care Resources (Ashgate, UK, 1998)

11. The World Medical Association. The World Medical Association Declaration of Helsinki, [online], $<\mathrm{http}: / /$ www. wma.net/e/policy/b3.htm> (adopted by the $52^{\text {nd }}$ General Assembly, Edinburgh, Scotland, October 2000).

12. United Nations. The Universal Declaration of Human Rights Articles 1 and 2, [online] <http://www.un.org/Overview/rights.html> (General Assembly resolution 217A (III), 10 December 1948).

13. Council of Europe. The European Convention on Human Rights Articles 2 and 14, [online],

<http://www.hri.org/docs/ECHR50.html> (Rome, 4 November 1950).
14. Hobbes, T. Leviathan (ed. Oakshott, M.) (Blackwell, Oxford, 1960).

15. Dworkin, R. Sovereign Virtue 1 (Harvard Univ. Press, 2000)

16. UNESCO. Universal Declaration on the Human Genome and Human Rights [online], <http://portal.unesco.org/shs/en/ev.php-

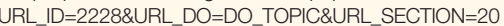
1.html $>$ (adopted by the General Conference of UNESCO on 11 November 1997).

17. Kahn, A. Clone mammals...clone man? Nature 386, 119 (1997).

18. McLaren, A. Opinion of the group of advisers on the ethical implications of biotechnology to the European Commission No 9. [online],

$<$ http://europa.eu.int/comm/european group ethics/gaieb /en/opinion9.pdf> (28 May 1997).

19. Kahn, A. Cloning, dignity and ethical revisionism. Nature 388, 320 (1997).

20. Harris, J. Is cloning an attack on human dignity? Nature 387, 754 (1997).

21. The European Court of Human Rights. Case of Vo v. France (application no. 53924/00) [online], $<$ http://www.echr.coe.int/Eng/Press/2004/July/GrandCha mberjudgmentVovFrance080704.htm> (Strasbourg, 8 July 2004).

22. Dworkin, R. Taking Rights Seriously Ch. 9 (Duckworth, London, 1977).

Acknowledgements

The authors acknowledge the support of a project grant from the European Commission for the project EUREKA under its Quality of Life and Management of Living Resources Programme, 2002. An important part of the impetus for this paper has come from the membership of both authors of the UK Human Genetics Commission (HGC). We thank all our colleagues on the commission for many helpful comments and suggestions but emphasize that the responsibility for this paper and for the ideas it contains is that of the authors and this paper does not necessarily represent the views nor the policy of HGC nor those of any other of its members. A version of the principle of genetic equity was originally proposed in an informal working paper by J.S., J.H. and Simona Giordano, called 'Genetic Equality' and submitted to the HGC. We thank two anonymous referees for helpful comments.

Competing interests statement

The authors declare that they have no competing financial interests.

\section{(4) Online links}

\section{FURTHER INFORMATION}

The World Medical Association Declaration of Human Rights: http://www.wma.net/e/policy/b3.htm/

Access to this interactive links box is free online.

\section{ONLINE CORRESPONDENCE $\searrow$}

Nature Reviews Genetics publishes items of correspondence online. Such contributions are published at the discretion of the Editors and are subject to peer review.

Correspondence should be a scholarly comment on a specific Review or Perspective article that has been published in the journal. To view the correspondence, please go to our home page at:

http://www.nature.com/reviews/genetics and select the link to New correspondence, or, alternatively, go to the archived correspondence at:

http://www.nature.com/nrg/archive/correspondence.

The following correspondence has recently been published:

Is all that junk really regulatory RNA?

By Anthony M. Poole

Reply:

John S. Mattick

This correspondence relates to the article:

RNA REGULATION: A NEW GENETICS?

John S. Mattick

Nature Reviews Genetics 5, 316-323 (2004) 